\title{
Fine Mapping of a Major QTL Influencing Morphine Preference in C57BL/6 and DBA/2 Mice Using Congenic Strains
}

\author{
Glenn A Doyle*,', Patrick J Furlong', Candice L Schwebel', George G Smith ${ }^{1,2}$, Falk W Lohoff', \\ Russell J Buono', Wade H Berrettini' and Thomas N Ferraro' \\ 'Department of Psychiatry, Center for Neurobiology and Behavior, University of Pennsylvania, Philadelphia, PA, USA; ${ }^{2}$ Research Service, \\ Department of Veterans Affairs Medical Center, Coatesville, PA, USA
}

\begin{abstract}
C57BL/6J (B6) and DBA/2J (D2) mice differ in behaviors related to substance abuse, including voluntary morphine consumption and preference in a two-bottle choice paradigm. Two major quantitative trait loci (QTL) for morphine consumption and preference exist between these strains on chromosomes (Chrs.) 6 and 10 when the two-bottle choice involves morphine in saccharin vs quinine in saccharin. Here, we report the refinement of the Chr. 10 QTL in subcongenic strains of D2.B6-Mop2 congenic mice described previously. With these subcongenic mouse strains, we have divided the introgressed region of Chr. 10 containing the QTL gene(s) into two segments, one between the acromere and Stxbp5 (in D2.B6-Mop2-PI mice) and the other between marker DI0Mit2II and marker DIOMit5I (in D2.B6-Mop2-D I mice). We find that, similar to B6 mice, the D2.B6-Mop2-PI congenic mice exhibit a strong preference for morphine over quinine, whereas D2.B6-Mop2-DI congenic mice avoid morphine (similar to D2 mice). We have also created a line of double congenic mice, B6.D2-Mop2.Qui, which contains both Chr. 10 and Chr. 6 QTL. We find that they are intermediate in their morphine preference scores when compared with B6 and D2 animals. Overall, these data suggest that the gene(s) involved in morphine preference in the morphine-quinine two-bottle choice paradigm are contained within the proximal region of Chr. 10 (which harbors Oprm I) between the acromere and Stxbp5, as well as on distal Chr. 6 between marker D6Mit 0 and the telomere. Neuropsychopharmacology (2008) 33, 280 I-2809; doi:I0.1038/npp.2008. I4; published online 20 February 2008
\end{abstract}

Keywords: mice; complex trait; quinine; opioids; behavior; drinking

\section{INTRODUCTION}

There is strong evidence that genetic factors are involved in determining individual differences in susceptibility to substance abuse and dependence, particularly with regard to heroin and other opiates (Tsuang et al, 2001). Given this fact, various animal models of substance abuse and dependence have been developed and are being used to identify genes involved in these disorders. To identify genes involved in substance abuse, we have used a common mouse model in which two mouse strains, C57BL/6J (B6) and DBA/2J (D2), differ in the expression of behaviors related to substances of abuse, including alcohol (Belknap et al, 1993b) and opiates (Belknap et al, 1993a). With respect to opiates, particularly morphine, B6 and D2 mice differ in voluntary intake (either by consumption of

\footnotetext{
*Correspondence: Dr GA Doyle, Department of Psychiatry, Center for Neurobiology and Behavior, University of Pennsylvania, I 25 South 3 I st Street, Philadelphia, PA 19104, USA,

Tel: + | 215898 |608, Fax: + | 215573204 I,

E-mail: gadoyle@mail.med.upenn.edu

Received 18 October 2007; revised 10 December 2007; accepted 22 January 2008
}

morphine-containing liquid or food, or by operant intravenous self administration) (Horowitz et al, 1977; Belknap et al, 1993a; Suzuki et al, 1991; Elmer GI, personal communication), development of tolerance (Frigeni et al, 1981) and dependence (Belknap, 1990; Suzuki et al, 1991), withdrawal symptoms (Suzuki et al, 1991; Kest et al, 2002), analgesia (Belknap et al, 1995), antinociception (Bergeson et al, 2001), Straub tail (Belknap, 1990), hypothermia (Muraki and Kato, 1987), and reward as determined by conditioned place preference (Cunningham et al, 1992; Orsini et al, 2005). Therefore, these two inbred mouse strains comprise a useful model for investigating the genetic influences on behaviors related to opiate/opioid abuse.

Berrettini et al (1994b) used a two-bottle choice paradigm in which B6 and D2 mice could drink a saccharin solution containing either morphine or quinine (Horowitz et al, 1977; Belknap et al, 1993a). A quantitative trait loci (QTL)mapping study, using this paradigm, revealed three regions of the mouse genome that explained greater than $85 \%$ of the observed genetic variance in preference for these substances - two major QTL on chromosomes (Chrs.) 10 and 6, and one minor QTL on Chr. 1 (Berrettini et al, 1994b). The Chr. 10 'Morphine-preference' (Mop) QTL was replicated (Alexander et al, 1996) and has been confirmed in reciprocal congenic mouse strains (Ferraro et al, 2005). 
The introgressed region in the aforementioned reciprocal congenic mouse strains, B6.D2-Mop2 and D2.B6-Mop2, was large ( $\sim 21 \mathrm{cM}$ from the acromere to D10Mit3) containing hundreds of genes. Nonetheless, the strongest candidate gene under the initial QTL peak and within the introgressed region was Oprm1, which encodes the main receptors for morphine in the brain - the $\mu$-opioid receptors (MORs) (Wood and Iyengar, 1988; Pan, 2005).

The main genetic influence on voluntary consumption of solutions containing various bitter-tasting compounds, including quinine, maps to the distal portion of Chr. 6 in mice (Lush, 1984; Nelson et al, 2005). Berrettini et al (1994b) suggested that the Qui locus for consumption of bitter-tasting compounds influenced the morphine preference scores in the two-bottle choice paradigm that was used to define the Mop QTL in B6 and D2 mice. Indeed, B6 and D2 mice differ in their intake of quinine in brief access $(6 \mathrm{~h})$ assays (Frank and Blizard, 1999; Boughter et al, 2005), as well as consumption of quinine in extended $(48 \mathrm{~h})$ water $v s$ quinine two-bottle choice experiments (Frank and Blizard, 1999), with B6 animals avoiding quinine more so than D2 animals. Additionally, mapping of the Qui locus has been further refined to the medial/distal region of Chr. 6 containing a cluster of Tas2 $\mathrm{r}$ taste receptor genes in the vicinity of $\operatorname{Prp}$ (marker D6Mit13) (Blizard et al, 1999; Adler et al, 2000; Chandrashekar et al, 2000; Nelson et al, 2005). A series of B6.D2 genome-tagged (congenic) mouse strains was recently created at the University of California at Los Angeles (UCLA) and made available to researchers (Iakoubova et al, 2001). As such, we obtained the B6.D2-6D mice and created a double congenic mouse strain, B6.D2Mop2.Qui that, in theory, would no longer exhibit aversion to quinine in the two-bottle choice paradigm because it would harbor the D2 qui locus, and, thus, show quininerelated behavior similar to that of D2 animals. Furthermore, these congenic mice might also serve to confirm the major QTL influencing morphine preference on distal Chr. 6 (Berrettini et al, 1994b).

In this paper, we report the creation of subcongenic mouse strains, D2.B6-Mop2-P1 and D2.B6-Mop2-D1, that break the previously reported QTL interval $(28.8 \mathrm{Mbp}$ in D2.B6-Mop2) on Chr. 10 (Ferraro et al, 2005) into two segments (9.5 Mbp in D2.B6-Mop2-P1 and $17.2 \mathrm{Mbp}$ in D2.B6-Mop2-D1), narrowing the introgressed region and substantially reducing the number of candidate genes that could account for the Mop2 morphine preference QTL. We report the results of experiments using these new subcongenic mouse strains with respect to voluntary morphine consumption behavior and morphine preference in a twobottle choice paradigm. We also report the results of experiments with a double congenic strain, B6.D2-Mop2. Qui, which was derived by breeding B6.D2-Mop2 (Ferraro et al, 2005) and B6.D2-6D congenic strains (Iakoubova et al, 2001).

\section{MATERIALS AND METHODS}

\section{Animals}

The animals used in these studies were derived from C57BL/ $6 \mathrm{~J}$ and $\mathrm{DBA} / 2 \mathrm{~J}$ mice originally purchased from Jackson Laboratory (Bar Harbor, ME) and propagated at our animal colony at the Department of Veterans Affairs Medical Center, Coatesville, PA. Genetic drift in the colony is minimized by supplementing breeders with additional animals purchased from the Jackson Laboratory several times per year. Mice are generally weaned at 3 weeks of age and group-housed by gender until used for experimentation. They are kept on a light/dark cycle of $14 \mathrm{~h}$ on (lights on at $0700 \mathrm{~h}$ ) and $10 \mathrm{~h}$ off and have free access to food. Water is available ad libitum except during the two-bottle choice paradigm described below. All studies were approved by the Animal Care and Use Committees governing the participating laboratories.

The B6.D2-Mop2 and D2.B6-Mop2 congenic mice used in these studies were created in our laboratory using a markerassisted breeding strategy as described (Ferraro et al, 2005). The D2.B6-Mop2-P1 and D2.B6-Mop2-D1 subcongenic strains were derived by backcrossing heterozygous D2.B6Mop2 congenic mice to parental D2 mice and tracking recombination by marker analysis within the original introgressed region. The B6.D2-Mop2.Qui double congenic mice used in these studies were created by crossing B6.D2Mop2 congenic mice (Ferraro et al, 2005) with B6.D2-6D (referred to here as B6.D2-Qui) congenic mice obtained from UCLA (Iakoubova et al, 2001). Standard markerassisted breeding (markers indicated in Figure 3) was used to create double congenic mice that were homozygous at each introgressed region.

\section{Two-Bottle Choice Experiments}

Mice 8-10 weeks old were housed separately for the duration of the 12-day two-bottle choice drinking experiment. Mice had free access to food throughout the experiment. On days 1-4 of the paradigm, mice were given two bottles filled with water to acclimate them to drinking from two bottles. On days 5-8 of the paradigm, mice were given a choice between $0.2 \%$ saccharin solutions containing either $0.4 \mathrm{mg} / \mathrm{ml}$ morphine sulfate or $0.2 \mathrm{mg} / \mathrm{ml}$ quinine. To control for effects due to learning, the positions of the bottles were changed daily. On days 9-12 of the paradigm, mice were given a choice between bottles filled with either $0.7 \mathrm{mg} / \mathrm{ml} \mathrm{morphine} \mathrm{sulfate} \mathrm{or} 0.4 \mathrm{mg} / \mathrm{ml}$ quinine in a $0.2 \%$ saccharin solution. Fluid intake was measured each day (at $0900-1000 \mathrm{~h}$ ) by weighing each bottle and calculating the amount of fluid ingested. Morphine consumption and preference scores were calculated as described previously (Berrettini et al, 1994b; Ferraro et al, 2005).

\section{Genotyping}

DNA marker analysis was performed by PCR amplification followed by electrophoresis on either polyacrylamide (Berrettini et al, 1994b) or agarose gels (Ferraro et al, 1998) as described previously. A single-nucleotide polymorphism (SNP) between B6 and D2 mice in exon 10 of Oprm1 that creates a DdeI site in B6 amplicons was analyzed as described (Ferraro et al, 2005). A second polymorphism in exon $115^{\prime}$ flank of Oprm1 was also analyzed. Briefly, a 960-bp product was amplified by PCR from $\sim 100 \mathrm{ng}$ of tail clip DNA using $1 \times$ standard Perkin Elmer PCR buffer containing $1.5 \mathrm{mM} \mathrm{MgCl}_{2}, 200 \mu \mathrm{M}$ dNTPs, $0.2 \mathrm{pmol} / \mu \mathrm{l}$ forward (5'-AGGGACCTTGTATGTAGAAATG-3 $\left.{ }^{\prime}\right)$ and reverse 
primers $\left(5^{\prime}\right.$-GAGTTATGGGAAGGGAGGAG-3'), $1 \mathrm{M}$ betaine, and $1 \mathrm{U}$ AmpliTaq DNA polymerase. PCR cycles were as follows: $94^{\circ} \mathrm{C}$ for $5 \mathrm{~min}$, followed by 35 cycles of $94^{\circ} \mathrm{C}$ for $30 \mathrm{~s}, 58^{\circ} \mathrm{C}$ for $30 \mathrm{~s}, 72^{\circ} \mathrm{C}$ for $90 \mathrm{~s}$, followed by $72^{\circ} \mathrm{C}$ for $5 \mathrm{~min}$. An A/G SNP creates a TspRI site (5'-CAGTG-3') in B6 mice that is absent in D2 mice. For genotyping, $10 \mu \mathrm{l}$ of the reaction was digested with $2 \mathrm{U}$ TspRI (New England Biolabs, Beverly, MA) at $65^{\circ} \mathrm{C}$ for $2 \mathrm{~h}$. The products were analyzed by separation on $5 \%$ non-denaturing polyacrylamide gels and staining with ethidium bromide, and were photographed with a video-based gel documentation system.

To fine-map the breakpoint in D2.B6-Mop2-P1 mice, polymorphisms in Grm1 and Stxbp5 on Chr. 10 were analyzed. For Grm1, a 165-bp amplicon was generated by PCR from $\sim 100 \mathrm{ng}$ of tail clip DNA using conditions as above for Oprm1, except for the exclusion of betaine and the use of Grm1-specific forward (5'-AGATGAGAGCCAGC TCCTTG- $\left.3^{\prime}\right)$ and reverse $\left(5^{\prime}\right.$-CACTCAAGTTCCTGCCA CAG-3') primers. PCR cycles were as follows: $94^{\circ} \mathrm{C}$ for $5 \mathrm{~min}$, followed by 35 cycles of $94^{\circ} \mathrm{C}$ for $30 \mathrm{~s}, 50^{\circ} \mathrm{C}$ for $30 \mathrm{~s}$, $72^{\circ} \mathrm{C}$ for $30 \mathrm{~s}$, followed by $72^{\circ} \mathrm{C}$ for $5 \mathrm{~min}$. An A/G SNP creates a PstI site $\left(5^{\prime}-\mathrm{CAGCTG}-3^{\prime}\right)$ in the D2, but not the B6 amplicon. For genotyping, $20 \mu \mathrm{l}$ of each reaction was digested with $10 \mathrm{U}$ Pst I (New England Biolabs) at $37^{\circ} \mathrm{C}$ for 1 h. For Stxbp5, a 221-bp amplicon was generated by PCR from $\sim 100 \mathrm{ng}$ of tail clip DNA using conditions as above for Oprm1, except for the use of Stxbp5-specific forward $\left(5^{\prime}\right.$-ACATGTGGAGGCCAAAGAAC- $\left.3^{\prime}\right)$ and reverse ( $5^{\prime}$-GGCTC TCAGGAGATGTGAGG- $3^{\prime}$ ) primers. PCR cycles were as follows: $94^{\circ} \mathrm{C}$ for $5 \mathrm{~min}$, followed by 35 cycles of $94^{\circ} \mathrm{C}$ for $30 \mathrm{~s}, 56^{\circ} \mathrm{C}$ for $30 \mathrm{~s}, 72^{\circ} \mathrm{C}$ for $30 \mathrm{~s}$, followed by $72^{\circ} \mathrm{C}$ for $5 \mathrm{~min}$. An A/G SNP creates a second $H p h I$ site $\left(5^{\prime}-\mathrm{GGTGA}(\mathrm{N})_{8^{-}} 3^{\prime}\right)$ in the B6 amplicon that is absent from the D 2 amplicon. For genotyping, $5 \mu \mathrm{l}$ of each reaction was digested with $10 \mathrm{U}$ $\mathrm{Hph}$ I (New England Biolabs) at $37^{\circ} \mathrm{C}$ for $1 \mathrm{~h}$. The products were analyzed as above.

Polymorphisms in the KapI and Tas2r105 genes on Chr. 6 were analyzed in B6.D2-Mop2.Qui animals. Briefly, for KapI, a 245-bp amplicon was generated by PCR from $\sim 100 \mathrm{ng}$ of tail clip DNA using conditions as above for Oprm1, except that the forward primer was $5^{\prime}$-GACTTCTTCACTAAGTGC TAAC- $3^{\prime}$, and the reverse primer was $5^{\prime}$-TGTTAGCCACCT GATCTCAAG-3 $3^{\prime}$. PCR cycles were as follows: $94^{\circ} \mathrm{C}$ for $5 \mathrm{~min}$, followed by 35 cycles of $94^{\circ} \mathrm{C}$ for $30 \mathrm{~s}, 56^{\circ} \mathrm{C}$ for $30 \mathrm{~s}$, $72^{\circ} \mathrm{C}$ for $30 \mathrm{~s}$, followed by $72^{\circ} \mathrm{C}$ for $5 \mathrm{~min}$. An A/G SNP creates an AluI site $\left(5^{\prime}-\mathrm{AGCT}-3^{\prime}\right)$ in the D2, but not in the B6, amplicon. For genotyping, $10 \mu \mathrm{l}$ of the reaction was digested with $2.5 \mathrm{U}$ of the AluI enzyme (New England Biolabs) at $37^{\circ} \mathrm{C}$ for at least $2 \mathrm{~h}$. For Tas2r105, a 1044-bp amplicon was amplified by PCR from $\sim 100 \mathrm{ng}$ of tail clip DNA under the conditions stated above for Oprm1, except for the addition of $0.8 \mu \mathrm{g} / \mu \mathrm{l}$ bovine serum albumin and the use of Tas2r105-specific forward (5'-GAACTCAATATA GAGGACACTC- $3^{\prime}$ ) and reverse (5'-CCCTCATTATTATTC TAAATTACGC- $3^{\prime}$ ) primers. PCR cycles were as follows: $94^{\circ} \mathrm{C}$ for $5 \mathrm{~min}$, followed by 35 cycles of $94^{\circ} \mathrm{C}$ for $30 \mathrm{~s}, 58^{\circ} \mathrm{C}$ for $30 \mathrm{~s}, 72^{\circ} \mathrm{C}$ for $80 \mathrm{~s}$, followed by $72^{\circ} \mathrm{C}$ for $5 \mathrm{~min}$. An A/G SNP creates an NheI site $\left(5^{\prime}\right.$-GCATGC- $\left.3^{\prime}\right)$ in the D2 strain that is not present in the B6 strain (Nelson et al, 2005). For genotyping, $10 \mu \mathrm{l}$ of the reaction was digested with $2.5 \mathrm{U}$ Nhe I (New England Biolabs) at $37^{\circ} \mathrm{C}$ for $90 \mathrm{~min}$. The products were analyzed as above.

\section{Data Analysis}

For each congenic line, at least two separate experiments were performed, which included the parental strains (B6 and D2) as controls. Multi-way ANOVA using the Truepistat software package (Epistat Services, Richardson, TX) was performed to determine whether there were effects of strain or experiment on the B6.D2-Mop2.Qui data. For D2.B6-Mop2-P1 and D2.B6-Mop2-D1 data, one-way ANOVAs for instances where there are different numbers of individuals in subsamples (ie. experiments) was used to calculate F using an Excel (Microsoft Corp., Seattle, WA) spreadsheet and the formulas contained in Statistical Methods by Snedecor (1950). Endpoints measured were not significantly different $(p<0.05)$ between genotypic groups studied in separate experiments. Thus, groups from separate experiments were combined for further analysis. One-way ANOVA was performed using Truepistat to determine whether there were strain effects within measures. One-way ANOVA and a post hoc Newman-Keuls analysis were performed using the Truepistat software package to determine confidence interval overlaps between strains. Graphs were plotted using Prism 4.0 software (GraphPad Software, San Diego, CA).

\section{In Silico Bioinformatics}

Brain expression of genes within the introgressed region of Chr. 10 in D2.B6-Mop2-P1 mice was determined initially by searching the Allen Brain Atlas (http://www.brainatlas.org/ $\mathrm{aba} /$ ) using the gene or cDNA name and accessing the densitometry graphs. Some cDNAs that were not in the atlas were documented as having been derived from brain tissue by checking the tissue source in the corresponding 'Nucleotide' record or by querying the 'Gene Expression Omnibus (GEO) profiles' at http://www.ncbi.nlm.nih.gov/ sites/entrez. We also searched the 'whole brain,' 'striatum,' 'cerebellum,' and 'hippocampus' gene chip expression profiles of $\mathrm{B} 6$ and $\mathrm{D} 2$ mice for each gene or cDNA at www.GeneNetwork.org (Wang et al, 2003) to verify brain expression. To determine whether there was any relationship between morphine pharmacology and the genes within the introgressed region in D2.B6-Mop2-P1 mice, a PubMed (http://www.ncbi.nlm.nih.gov/sites/entrez) literature search was performed for each gene or cDNA using various search terms (full gene name, gene symbol, and so on) in combination with 'morphine,' ' $\mu$-opioid receptor,' or 'opiate.'

\section{RESULTS}

\section{B6 D2-Mop2.Qui Two-Bottle Choice Experiments}

Two separate experiments were performed using the B6.D2Mop2.Qui double congenic strain. There was no effect of experiment for the B6.D2-Mop2.Qui data sets $(\mathrm{F}=1.130$ 1.956, $p=0.17-0.294)$. Therefore, B6.D2-Mop2.Qui groups from each experiment were combined for further analysis. In experiments with the B6.D2-Mop2.Qui strain, a strong effect of strain was seen on morphine and quinine consumption $\left(\mathrm{F}=111.282, p<1 \times 10^{-8}\right.$ and $\mathrm{F}=13.33$, $p=3.88 \times 10^{-5}$, respectively) and for total fluid $(\mathrm{F}=48.66$, 
$\left.p<1 \times 10^{-8}\right)$ and morphine preference $(\mathrm{F}=21.771$, $\left.p=4 \times 10^{-7}\right)$.

We hypothesized that if the introgressed region of Chr. 6 in double congenic B6.D2-Mop2.Qui mice contained the gene cluster for bitter-tasting compounds that controls quinine aversion in B6 mice (Adler et al, 2000; Chandrashekar et al, 2000; Nelson et al, 2005), then they would exhibit a reduced preference for morphine compared with B6 and B6.D2-Mop2 animals (Ferraro et al, 2005). As predicted and similar to D2 mice, the B6.D2-Mop2.Qui mice consume significantly more quinine than B6 (Figure 1, $p<0.01$ ) and B6.D2-Mop2 mice (Ferraro et al, 2005) $(32.7 \pm 16.9$ vs $6.74 \pm 3.28$, respectively, Student's $t$-test, $\left.p=3.6 \times 10^{-10}\right)$. However, B6.D2-Mop2.Qui mice consume significantly more morphine than D2 mice, but significantly less than B6 mice (Figure 1, $p<0.01$ ). Thus, morphine preference of the B6.D2-Mop2.Qui strain was reduced significantly compared with B6 (Figure 2) and B6.D2Mop2 (Ferraro et al, 2005) strains. B6.D2-Mop2.Qui mice

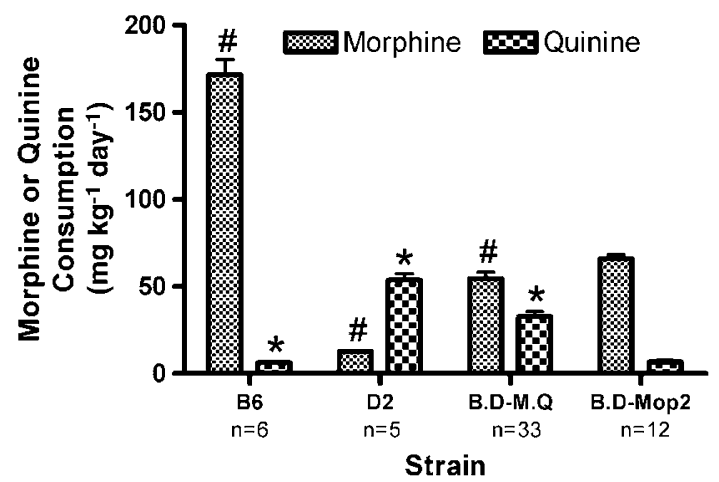

Figure I Morphine and quinine consumption by parental and B6.D2Mop2.Qui congenic mice. Mice were tested in the two-bottle choice paradigm with saccharin plus morphine or quinine as described under Materials and Methods. The mean (+ SEM) consumption over days 9-12 is shown. The number of animals in each strain group is indicated. ${ }^{*} p<0.01$ vs all other strain groups for quinine consumption; ${ }^{\#} p<0.0$ I vs all other strain groups for morphine consumption. The data for B6.D2-Mop2 mice are from Ferraro et al (2005). Note that symbols indicating significance do not apply to B.D-Mop2 data.

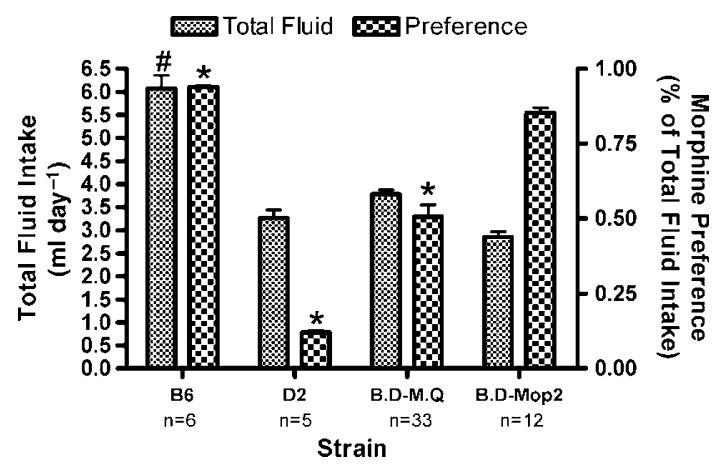

Figure 2 Morphine preference and total fluid intake by parental and B6.D2-Mop2.Qui congenic mice. Mice were tested in the two-bottle choice paradigm with saccharin plus morphine or quinine as described under Materials and Methods. The mean (+ SEM) preference scores and total fluid intake over days $9-12$ is shown. The number of animals in each strain group is indicated. ${ }^{*} p<0.0$ I vs all other strains for morphine preference; \# $p<0.0$ I vs all other strains for total fluid intake. The data for B6.D2-Mop2 mice are from Ferraro et al (2005). Note that symbols indicating significance do not apply to B.D-Mop2 data. show $60 \%$ of the preference for morphine compared with B6.D2-Mop2 mice (Ferraro et al, 2005) (0.51 \pm 0.22 vs $0.85 \pm 0.06$, respectively, Student's t-test, $p=4 \times 10^{-10}$ ). These data suggest that $40 \%$ of morphine preference might be explained simply by taste factors (Lush, 1984; Berrettini et al, 1994b; Ferraro et al, 2005) and are in agreement with earlier work indicating that the QTL on Chr. 6 explains roughly $36 \%$ of the genetic variance in morphine consumption between the B6 and D2 strains (Berrettini et al, 1994b). The difference in morphine preference can be attributed partially to increased consumption of quinine by B6.D2Mop2.Qui mice (Figure 1), which consume approximately four and a half times more quinine than B6.D2-Mop2 mice (Ferraro et al, 2005) $(32.7 \pm 16.9$ vs $6.7 \pm 3.3 \mathrm{mg} / \mathrm{kg} / \mathrm{day}$, respectively, Student's $t$-test, $\left.p=3.6 \times 10^{-10}\right)$. These data suggest that the Chr. 6 QTL influencing quinine aversion in B6 mice (Berrettini et al, 1994b; Blizard et al, 1999) has been captured in the B6.D2-Mop2.Qui congenic strain. However, the B6.D2-Mop2.Qui morphine preference score remains higher than that of D2 animals $(0.51 \pm 0.22$ vs $0.12 \pm 0.02$, Student's $t$-test, $p=2.4 \times 10^{-11}$; Figure 2$)$, suggesting the presence of additional alleles (loci) in D2 mice that influence morphine and/or quinine consumption.

Genetic Characterization of D2.B6-Mop2-P1 and D2.B6Mop2-D1 Subcongenic Mice

Since the initial report on the D2.B6-Mop2 congenic mice (Ferraro et al, 2005), we have continued to backcross these animals to their parental strain (D2) to generate subcongenic strains for refined mapping of the QTL on Chr. 10. Thus, we created the D2.B6-Mop2-P1 and D2.B6-Mop2-D1 subcongenic strains (see Figure 3 for map) and tested them for morphine consumption and preference. Notably, these strains are most useful for fine mapping of the Mop2 QTL because they do not have the complication of quinine aversion as does the reciprocal B6.D2-Mop2 strain. The original D2.B6-Mop2 congenic mice contain an introgressed region from B6 $\mathrm{Chr}$. 10 that is approximately $21 \mathrm{cM}$, extending from the acromere to marker D10Mit3 (Ferraro et al, 2005). The subcongenic mice, D2.B6-Mop2-P1 and D2.B6-Mop2-D1, used here have divided this region into two segments, with the breakpoint between markers D10Mit28 and D10Mit211 (Figure 3). Fine mapping of genes within the breakpoint region revealed that both D2.B6-Mop2-P1 and D2.B6-Mop2-D1 mice were homozygous for the D2 allele at the Grm1 and Stxbp5 loci. Thus, D2.B6-Mop2-P1 mice contain B6 sequence from the acromere to marker D10Mit28, whereas D2.B6-Mop2-D1 mice contain B6 sequence between marker D10Mit211 and marker D10Mit51.

\section{D2.B6-Mop2-P1 and D2.B6-Mop2-D1 Two-Bottle Choice Experiments}

Three separate two-bottle choice experiments were performed using D2.B6-Mop2-P1 and D2.B6-Mop2-D1 congenic strains. One-way ANOVA revealed no experimental effect on any measures in the four strains tested. Therefore, data from animals in the three experiments with these congenic strains were combined for further analysis. One-way ANOVA revealed large strain effects for 


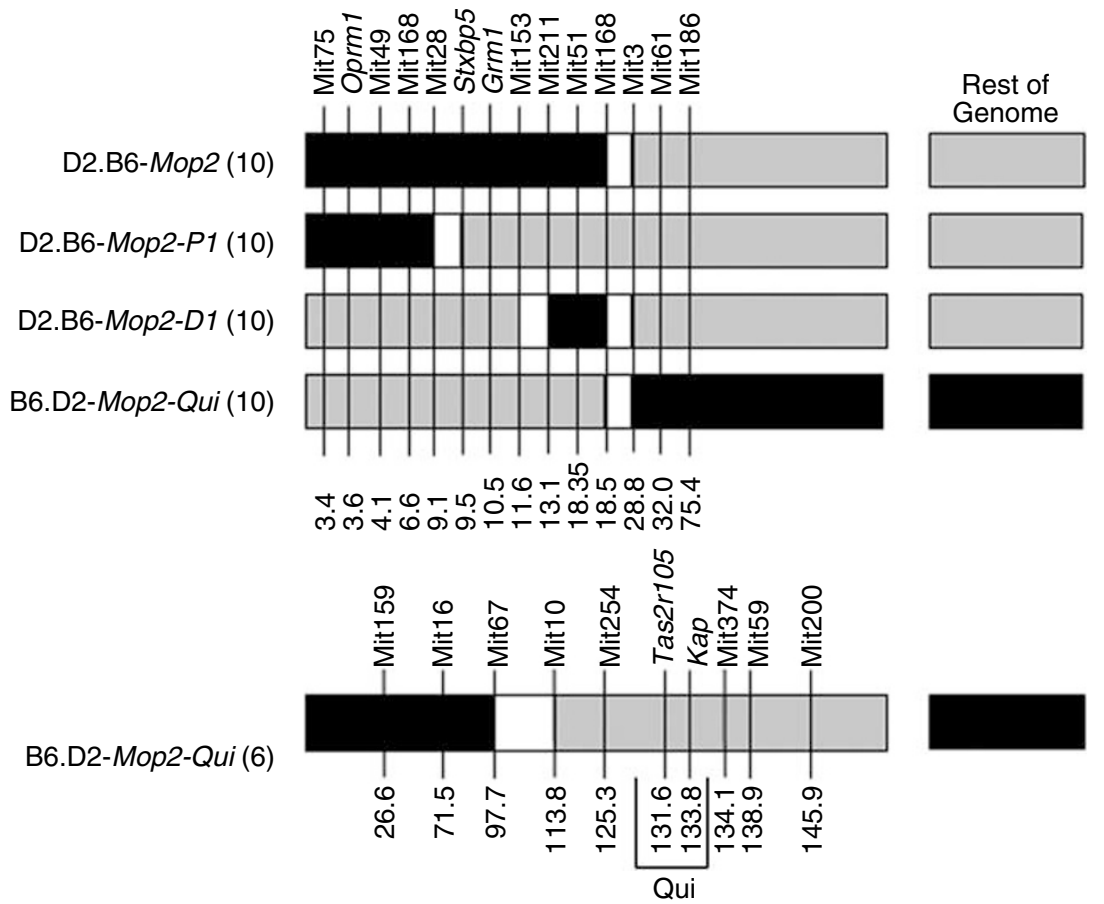

Figure 3 Schematic representation of Chrs. 10 and 6 in congenic strains tested in the two-bottle choice paradigm. The chromosome number presented is indicated in parentheses. The names of genes and DNA microsatellite markers that were typed for these studies are given above each chromosome. Their relative positions (in Mbp from the acromere) on the physical map (http://genome.ucsc.edu) are given below the chromosome. Black regions reflect contributions from the B6 parental strain, while gray regions reflect contributions from the D2 parental strain. White regions between markers and/or genes indicate regions of undetermined origin. The position of the Qui locus as defined by Nelson et al (2005), which agrees well with the morphine preference QTL peak (from 100 to 130 Mbp centered on D6Mit I3) mapped by Berrettini et al (1994b), is indicated. The position of the original Chr. 10 morphine preference QTL peak was localized between markers DIOMit28 at roughly 9.I Mbp and DIOMitI5 at 66.4 Mbp.

quinine $\left(\mathrm{F}=72.782, p<1 \times 10^{-8}\right)$ and morphine consumption $\left(\mathrm{F}=44.447, p<1 \times 10^{-8}\right)$, as well as for total fluid intake $\left(\mathrm{F}=28.656, p<1 \times 10^{-8}\right)$ and morphine preference $\left(\mathrm{F}=226.647, p<1 \times 10^{-8}\right)$.

D2.B6-Mop2-D1 and D2 mice consumed similar (not statistically different) amounts of quinine, which differed significantly from quinine consumption of D2.B6-Mop2-P1 and B6 mice $(p<0.01)$ (Figure 4). Moreover, D2.B6-Mop2$P 1$ and $\mathrm{B} 6$ mice were significantly different $(p<0.05)$ from each other in quinine consumption (Figure 4). In terms of morphine consumption, B6 mice drank more than any other strain (Figure 4, $p<0.01$ ). D2.B6-Mop2-P1 mice consumed an intermediate amount of morphine, drinking significantly more than D2 and D2.B6-Mop2-D1 mice (Figure $4, p<0.01$ ), but significantly less than B6 mice (Figure $4, p<0.01$ ). As with quinine consumption, D2 and D2.B6-Mop2-D1 mice did not differ in their morphine consumption (Figure 4). B6 mice were statistically different from all other strains in total fluid intake (Figure 5, $p<0.01)$. With respect to morphine preference, B6 and D2.B6-Mop2-P1 mice showed highest preference and were statistically different from all other strains $(p<0.01$; see Figure 5). D2 and D2.B6-Mop2-D1 mice were not statistically different in morphine preference (Figure 5).

Overall, as with the original D2.B6-Mop2 congenic animals (Ferraro et al, 2005), D2.B6-Mop2-P1 mice exhibit behavior resembling that which is characteristic of B6 mice (Figures 4 and 5). Conversely, D2.B6-Mop2-D1 mice resemble D2 mice in drinking behavior (Figures 4 and 5). D2.B6-Mop2-P1 congenic mice drank approximately $50 \%$ as

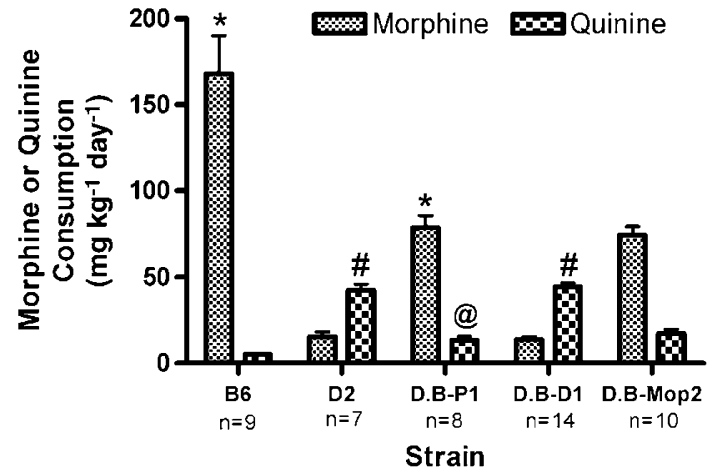

Figure 4 Morphine and quinine consumption by parental and D2.B6Mop2-PI and D2.B6-Mop2-DI subcongenic mice. Mice were tested in the two-bottle choice paradigm with saccharin plus morphine or quinine as described under Materials and Methods. The mean (+SEM) consumption over days $9-12$ is shown. The number of animals in each strain group is indicated. $* p<0.01$ vs all other strains for morphine consumption; ${ }^{\#} p<0.01$ vs B6 and PI strains for quinine consumption; ${ }^{\circledR} p<0.05$ vs B6, $p<0.01$ vs $D 1$ and D2 strains for quinine consumption. The data for D2.B6-Mop2 mice are from Ferraro et al (2005). Note that symbols indicating significance do not apply to D.B-Mop2 data.

much morphine as B6 mice, but still showed high morphine preference scores relative to $\mathrm{D} 2$ mice $(0.77 \pm 0.11$ for $\mathrm{P} 1 v \mathrm{~s}$ $0.18 \pm 0.10$ for D2) (Figure 5). Importantly, the morphine preference score of D2.B6-Mop2-P1 mice approximates that of D2.B6-Mop2 mice ( $0.77 \pm 0.11$ vs $0.71 \pm 0.12$, respectively) (Ferraro et al, 2005). The fact that D2.B6-Mop2-P1 animals drink less morphine than B6 animals can be explained by a 


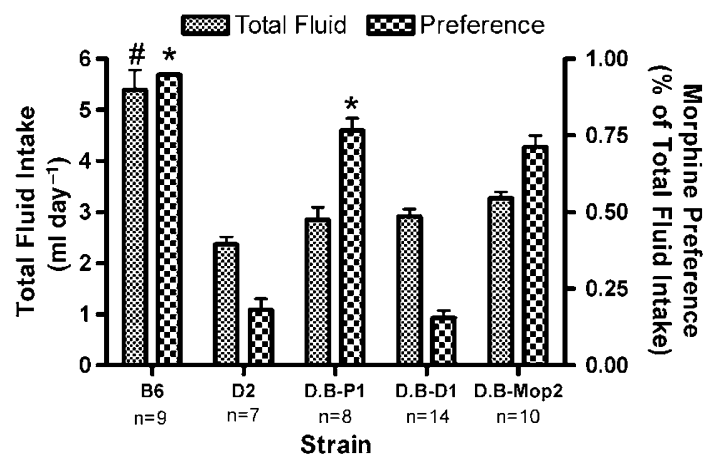

Figure 5 Morphine preference and total fluid intake by parental and D2.B6-Mop2-PI and D2.B6-Mop2-DI subcongenic mice. Mice were tested in the two-bottle choice paradigm with saccharin plus morphine or quinine as described under Materials and Methods. The mean (+ SEM) preference scores and total fluid intake over days $9-12$ is shown. The number of animals in each strain group is indicated. $* p<0.0$ I vs all other strains for morphine preference; ${ }^{\#} p<0.0$ I vs all other strains for total fluid intake. The data for D2.B6-Mop2 mice are from Ferraro et al (2005). Note that symbols indicating significance do not apply to D.B-Mop2 data.

lack of quinine aversion found on the D2 background. This fact may also play some role in determining the slightly lower morphine preference scores for D2.B6-Mop2-P1 mice when compared with B6 preference scores $(0.95 \pm 0.01$ for B6 vs $0.77 \pm 0.11$ for P1) (Figure 5). In contrast, D2.B6Mop2-D1 mice show morphine preference scores similar to D2 mice $(0.16 \pm 0.08$ for D1 vs $0.18 \pm 0.10$ for D2) (Figure 5). These data suggest that D2.B6-Mop2-P1 mice still harbor the gene(s) responsible for the Chr. 10 QTL, whereas D2.B6Mop2-D1 mice do not. Therefore, this places the Mop2 QTL gene(s) within the region of Chr. 10 between the acromere and the Stxbp5 locus.

\section{Brain Expression of Candidate Genes}

Of the $39 \mathrm{~B} 6$-derived genes or cDNAs in the critical interval of D2.B6-Mop2-P1 mice, at least 35 are expressed at some minimal level in at least one brain region. There are five genes harbored within the introgressed region of D2.B6Mop2-P1 mice whose products have been documented to be related to morphine pharmacology, including Ppp1r14c (Liu et al, 2002), Iyd (Baumgartner et al, 1998), Vip (Liu et al, 2004), Rgs17 (Garzon et al, 2005a, b; Rodriguez-Munoz et al, 2007a, b), and Oprm1 (Contet et al, 2004; Pasternak, 2001b). Although we cannot fully exclude those genes within the introgressed region that have unknown relationships to morphine pharmacology, of those mentioned above, we consider the two strongest candidate genes to be Oprm1 and Rgs17 (see below).

\section{DISCUSSION}

Results obtained from studying B6.D2-Mop2.Qui double congenic strain suggest that $40 \%$ of morphine preference is attributable to loci on the distal portion of Chr. 6 (Figure 2), from marker D6Mit10 to the telomere (Figure 3). This result most likely represents the influence of the Qui locus near marker D6Mit13 (Berrettini et al, 1994b; Blizard et al, 1999). The fact that B6.D2-Mop2.Qui double congenic mice drink approximately $50 \%$ of their fluid from the morphine-containing bottle indicates that they no longer have a 'preference' for one solution or the other. On the other hand, B6.D2-Mop2.Qui mice show a significantly higher preference for morphine compared with D2 mice (Figure 2). This difference may reflect other taste preferences of D2 and B6 mice. For example, in brief access tests, D2 mice have a relative taste aversion to saccharin solutions containing morphine compared with the B6 strain (Horowitz et al, 1977). However, the magnitude of difference between these strains in our previous data (Ferraro et al, 2005) is smaller than that observed by Horowitz et al (1977), possibly because of the extended nature of our paradigm and because we compared morphine-saccharin to saccharin rather than to water. The B6.D2-Mop2.Qui strain maintains the B6 allele of the Sac locus for sweet-tasting compounds on Chr. 4 (Blizard et al, 1999; Nelson et al, 2001; Zhao et al, 2003). Thus, there is the possibility that the greater preference for the morphine-saccharin solution of B6.D2-Mop2.Qui mice, as compared with the D2 strain, reflects some interaction of the Sac locus with the bitter taste loci on Chr. 6 or elsewhere in the genome. Taken together with previously published data demonstrating that morphine preference in the twobottle choice paradigm was diminished by $50 \%$ upon administration of naltrexone (Berrettini et al, 1994a), these results suggest that at least $10 \%$ of morphine preference is not explained by the QTL on Chrs. 6 and 10. Notably, previous work identified a suggestive QTL $(\operatorname{Lod}=3.1)$ on Chr. 1 that explained about $10 \%$ of the genetic variance between the parental B6 and D2 strains (Berrettini et al, 1994b). Thus, an allele on Chr. 1 may also contribute to the difference in morphine consumption and/or preference observed between the B6.D2-Mop2.Qui and D2 strains. Alternatively, more pronounced peripheral effects of morphine, such as nausea or constipation, in D2 mice might cause them to avoid the morphine solution.

Comparison of congenic strains created to refine the $\mathrm{Chr}$. 10 QTL reveals that the D2.B6-Mop2-P1 subcongenic strain behaves similarly to the D2.B6-Mop2 congenic strain used for the initial QTL confirmation (Ferraro et al, 2005), showing B6-like morphine preference (Figure 5). The introgressed region in the D2.B6-Mop2 congenic strain was relatively large $(\sim 21 \mathrm{cM}$ from the acromere to D10Mit3) compared with that of the D2.B6-Mop2-P1 subcongenic strain $(\sim 4 \mathrm{cM}$ from the acromere to Stxbp5). Fine mapping of the breakpoint between markers D10Mit28 and D10Mit153 in D2.B6-Mop2-P1 congenic mice identified D2 alleles at the Grm1 and Stxbp5 loci. According to Ensembl (release 46, mouse genome build 36), there are 37 known or novel genes or CDNAs between the acromere and marker D10Mit28, and an additional two novel genes or cDNAs between marker D10Mit28 and Stxbp5. Therefore, we conservatively estimate that there are 39 B6-derived candidate genes or cDNAs remaining within the introgressed region of Chr. 10 in D2.B6-Mop2-P1 congenic mice, one or more of which contains a variation(s) that has a major influence on the difference in morphine consumption and preference between $\mathrm{B} 6$ and D2 mice.

A recent paper describing the mouse SNP Miner database (Reuveni et al, 2007) attempted to identify the causative gene(s) for morphine consumption within the introgressed region of Chr. 10 of the B6.D2-Mop2 and/or D2.B6-Mop2 
reciprocal congenic strains (Ferraro et al, 2005). Reuveni et al (2007) note that Syne1 and Gpr126 both have variations in D2 mice predicted to be functionally deleterious by their algorithm(s), but rule out Syne1 because the splice variant containing the critical (perhaps functional) SNP in this gene is not expressed in the brain (Reuveni et al, 2007). Therefore, they propose that the orphan G-protein-coupled receptor Gpr126 is a good candidate gene for the morphine consumption QTL (Reuveni et al, 2007). Results with subcongenic strains reported here argue strongly against Gpr126 being the causative Mop2 QTL gene, however, as the B6 allele remains harbored in the D2.B6-Mop2-D1 animals, which show low preference for morphine, whereas the D2.B6-Mop2-P1 animals (which show high morphine preference; Figure 5) possess the D2 allele at Gpr126. Conversely, B6 alleles for Syne1 are harbored in the D2.B6Mop2-P1 animals and, thus, this gene remains a candidate for further analysis.

Results of the present study indicate that the major genetic influence mediating the difference in morphine consumption and/or preference between B6 and D2 mice arises from the most proximal portion of Chr. 10 between the acromere and Stxbp5. The MOR gene (Oprm1) spans approximately $250 \mathrm{~kb}$ of proximal Chr. 10 (Kozak et al, 1994; Giros et al, 1995) and contains at least 19 alternatively spliced exons (Doyle et al, 2007a,b) that encode a number of MOR isoforms capable of binding morphine, other opiates, and endogenous opioid peptides (Pan et al, 1999, 2000, 2001, 2005; Pan, 2005; Bolan et al, 2004). There is ample pharmacological evidence that MORs represent the major sites of interaction of clinically used opioid analgesics, particularly morphine (Pasternak, 2001a). Their role in morphine-based responses, including analgesia, tolerance, dependence and withdrawal, respiratory depression, and hypothermia, has been confirmed in various MOR-knockout mouse lines (Matthes et al, 1996; Sora et al, 1997; Tian et al, 1997; Loh et al, 1998; Schuller et al, 1999). Thus, we believe that Oprm1 remains the strongest candidate gene for explaining the Mop2 QTL because (1) it functions as the main receptor for morphine in the brain (Pasternak, 2001a), (2) the B6 allele remains within the introgressed region in D2.B6-Mop2-P1 animals, which show high morphine consumption and preference, (3) studies with naltrexone suggest a receptor-based B6 morphine preference phenotype (Berrettini et al, 1994a), and (4) it harbors coding and non-coding polymorphisms that may have functional significance (data not shown; Ferraro et al, 2005; Doyle et al, 2006). Therefore, results of studies on the D2.B6-Mop2-P1 subcongenic strain continue to support the hypothesis regarding Oprm1 as the causative gene for the Chr. 10 morphine preference QTL.

Despite strong circumstantial evidence suggesting that variation in Oprm1 represents the quantitative trait gene for the Chr. 10 QTL, preliminary data in our laboratory indicate differences in expression levels for Rgs 17 mRNA in naïve brain tissue from D2 and B6 mice (data not shown). We do not yet know what influence morphine might have on these expression differences. Nonetheless, the regulator of G-protein signaling 17 (Rgs17, aka RgsZ2) exists in a complex with the MOR (Garzon et al, 2005a; RodriguezMunoz et al, 2007a) and morphine regulates Rgs17mediated MOR desensitization and internalization in neurons (Rodriguez-Munoz et al, 2007b), as well as its association with Rgs17 in brain (Garzon et al, 2005b). It is important to note that because Rgs17 is involved in MOR desensitization, it too might have been affected by the MOR antagonist naltrexone (Berrettini et al, 1994a). Thus, Rgs17 is another strong candidate gene within the introgressed region of D2.B6-Mop2-P1 mice.

In conclusion, the Oprm1 and Rgs17 genes may both contribute (along with other genes remaining within the critical interval) to the differences seen in voluntary oral morphine consumption and/or preference. If this is the case, perhaps the most feasible way to differentiate their relative involvements is by using congenic mice. A fortuitous breakpoint at marker D10Mit49 (which lies between Oprm1 and Rgs17) would facilitate the identification of the causative gene(s) for this QTL. Thus, we continue our attempts to further refine the QTL by additional backcrossing of D2.B6-Mop2-P1 congenic mice to the D2 parental strain, while also conducting molecular genetic studies on Rgs17 and Oprm1 in B6 and D2 mice.

\section{ACKNOWLEDGEMENTS}

This work was supported by NIH Grant DA14008, by NIDA grant P60 05186 to Charles O'Brien, MD, PhD, Veterans Administration VISN4 Mental Illness Research, Education and Clinical Center (David Oslin, MD, PI), and by a grant from Philip and Marcia Cohen. The mouse work presented was supported by use of Veterans Affairs facilities at Coatesville Veterans Affairs Medical Center.

\section{DISCLOSURE/CONFLICT OF INTEREST}

The authors declare that there are no personal financial holdings or compensations that could be perceived as constituting potential conflict of interest for this work.

\section{REFERENCES}

Adler E, Hoon MA, Mueller KL, Chandrashekar J, Ryba NJ, Zuker CS (2000). A novel family of mammalian taste receptors. Cell 100: 693-702.

Alexander RC, Heydt D, Ferraro TN, Vogel W, Berrettini WH (1996). Further evidence for a quantitative trait locus on murine chromosome 10 controlling morphine preference in inbred mice. Psychiatr Genet 6: 29-31.

Baumgartner A, Pinna G, Hiedra L, Bauer F, Wolf J, Eravci M et al (1998). Effects of acute administration of ethanol and the muopiate agonist etonitazene on thyroid hormone metabolism in rat brain. Psychopharmacology (Berl) 135: 63-69.

Belknap JK (1990). Physical dependence induced by the voluntary consumption of morphine in inbred mice. Pharmacol Biochem Behav 35: 311-315.

Belknap JK, Crabbe JC, Riggan J, O’Toole LA (1993a). Voluntary consumption of morphine in 15 inbred mouse strains. Psychopharmacology (Berl) 112: 352-358.

Belknap JK, Crabbe JC, Young ER (1993b). Voluntary consumption of ethanol in 15 inbred mouse strains. Psychopharmacology (Berl) 112: 503-510.

Belknap JK, Mogil JS, Helms ML, Richards SP, O’Toole LA, Bergeson SE et al (1995). Localization to chromosome 10 of a locus influencing morphine analgesia in crosses derived from C57BL/6 and DBA/2 strains. Life Sci 57: PL117-PL124. 
Bergeson SE, Helms ML, O’Toole LA, Jarvis MW, Hain HS, Mogil JS et al (2001). Quantitative trait loci influencing morphine antinociception in four mapping populations. Mamm Genome 12: $546-553$.

Berrettini WH, Alexander R, Ferraro TN, Vogel WH (1994a). A study of oral morphine preference in inbred mouse strains. Psychiatr Genet 4: 81-86.

Berrettini WH, Ferraro TN, Alexander RC, Buchberg AM, Vogel WH (1994b). Quantitative trait loci mapping of three loci controlling morphine preference using inbred mouse strains. Nat Genet 7: 54-58.

Blizard DA, Kotlus B, Frank ME (1999). Quantitative trait loci associated with short-term intake of sucrose, saccharin and quinine solutions in laboratory mice. Chem Senses 24: 373-385.

Bolan EA, Pan YX, Pasternak GW (2004). Functional analysis of MOR-1 splice variants of the mouse mu opioid receptor gene Oprm. Synapse 51: 11-18.

Boughter Jr JD, Raghow S, Nelson TM, Munger SD (2005). Inbred mouse strains $\mathrm{C} 57 \mathrm{BL} / 6 \mathrm{~J}$ and $\mathrm{DBA} / 2 \mathrm{~J}$ vary in sensitivity to a subset of bitter stimuli. BMC Genet 6: 36 .

Chandrashekar J, Mueller KL, Hoon MA, Adler E, Feng L, Guo W et al (2000). T2Rs function as bitter taste receptors. Cell 100: 703-711.

Contet C, Kieffer BL, Befort K (2004). Mu opioid receptor: a gateway to drug addiction. Curr Opin Neurobiol 14: 370-378. Review.

Cunningham CL, Niehus DR, Malott DH, Prather LK (1992). Genetic differences in the rewarding and activating effects of morphine and ethanol. Psychopharmacology (Berl) 107: 385-393.

Doyle GA, Sheng XR, Lin SS, Press DM, Grice DE, Buono RJ et al (2007a). Identification of three mouse mu-opioid receptor (MOR) gene (Oprm1) splice variants containing a newly identified alternatively spliced exon. Gene 388: 135-147, (originally published online Nov. 1, 2006, as doi:10.1016/j. gene.2006.10.017).

Doyle GA, Sheng XR, Lin SS, Press DM, Grice DE, Buono RJ et al (2007b). Identification of five mouse mu-opioid receptor (MOR) gene (Oprm1) splice variants containing a newly identified alternatively spliced exon. Gene 395: 98-107, (originally published online Feb. 20, 2007, as doi:10.1016/j.gene.2007. 02.004).

Doyle GA, Sheng XR, Schwebel CL, Ferraro TN, Berrettini WH, Buono RJ (2006). Identification and functional significance of polymorphisms in the mu-opioid receptor gene (Oprm) promoter of C57BL/6 and DBA/2 mice. Neurosci Res 55: 244-254, (originally published online Apr. 27, 2006, as doi:10.1016/j.neures.2006.03.005).

Ferraro TN, Golden GT, Smith GG, Martin JF, Schwebel CL, Doyle GA et al (2005). Confirmation of a major QTL influencing oral morphine intake in C57 and DBA mice using reciprocal congenic strains. Neuropsychopharmacology 30: 742-746.

Ferraro TN, Schill JF, Ballas C, Mulholland N, Golden GT, Smith GG et al (1998). Genotyping microsatellite polymorphisms by agarose gel electrophoresis with ethidium bromide staining: application to quantitative trait loci analysis of seizure susceptibility in mice. Psychiatr Genet 8: 227-233.

Frank ME, Blizard DA (1999). Chorda tympani responses in two inbred strains of mice with different taste preferences. Physiol Behav 67: 287-297, review.

Frigeni V, Bruno F, Carenzi A, Racagni G (1981). Difference in the development of tolerance to morphine and D-ALA2-methionineenkephalin in C57 BL/6J and DBA/2J mice. Life Sci 28: 729-736.

Garzon J, Rodriguez-Munoz M, Lopez-Fando A, Sanchez-Blazquez P (2005a). The RGSZ2 protein exists in a complex with mu-opioid receptors and regulates the desensitizing capacity of $\mathrm{Gz}$ proteins. Neuropsychopharmacology 30: 1632-1648.

Garzon J, Rodriguez-Munoz M, Sanchez-Blazquez P (2005b). Morphine alters the selective association between mu-opioid receptors and specific RGS proteins in mouse periaqueductal gray matter. Neuropharmacology 48: 853-868.

Giros B, Pohl M, Rochelle JM, Seldin MF (1995). Chromosomal localization of opioid peptide and receptor genes in the mouse. Life Sci 56: PL369-PL375.

Horowitz GP, Whitney G, Smith JC, Stephan FK (1977). Morphine ingestion: genetic control in mice. Psychopharmacology (Berl) 52: $119-122$.

Iakoubova OA, Olsson CL, Dains KM, Ross DA, Andalibi A, Lau K et al (2001). Genome-tagged mice (GTM): two sets of genomewide congenic strains. Genomics 74: 89-104.

Kest B, Palmese CA, Hopkins E, Adler M, Juni A, Mogil JS (2002). Naloxone-precipitated withdrawal jumping in 11 inbred mouse strains: evidence for common genetic mechanisms in acute and chronic morphine physical dependence. Neuroscience 115: 463-469.

Kozak CA, Filie J, Adamson MC, Chen Y, Yu L (1994). Murine chromosomal location of the mu and kappa opioid receptor genes. Genomics 21: 659-661.

Liu NJ, Chakrabarti S, Gintzler AR (2004). Chronic morphineinduced loss of the facilitative interaction between vasoactive intestinal polypeptide and delta-opioid: involvement of protein kinase $C$ and phospholipase $C$ betas. Brain Res 1010: 1-9.

Liu QR, Zhang PW, Zhen Q, Walther D, Wang XB, Uhl GR (2002). KEPI, a PKC-dependent protein phosphatase 1 inhibitor regulated by morphine. J Biol Chem 277: 13312-13320, (originally published online Jan. 25, 2002, as doi:10.1074/jbc. M107558200).

Loh HH, Liu HC, Cavalli A, Yang W, Chen YF, Wei LN (1998). $\mathrm{Mu}$ opioid receptor knockout in mice: effects on ligand-induced analgesia and morphine lethality. Brain Res Mol Brain Res 54: 321-326.

Lush IE (1984). The genetics of tasting in mice. III. Quinine. Genet Res 44: 151-160.

Matthes HW, Maldonado R, Simonin F, Valverde O, Slowe S, Kitchen I et al (1996). Loss of morphine-induced analgesia, reward effect and withdrawal symptoms in mice lacking the muopioid-receptor gene. Nature 383: 819-823.

Muraki T, Kato R (1987). Genetic analysis of hypothermia induced by morphine in two strains of inbred mice. Pharmacol Biochem Behav 27: 87-91.

Nelson G, Hoon MA, Chandrashekar J, Zhang Y, Ryba NJP, Zuker CS (2001). Mammalian sweet taste receptors. Cell 106: 381-390.

Nelson TM, Munger SD, Boughter Jr JD (2005). Haplotypes at the Tas2r locus on distal chromosome 6 vary with quinine taste sensitivity in inbred mice. BMC Genet 6: 32.

Orsini C, Bonito-Oliva A, Conversi D, Cabib S (2005). Susceptibility to conditioned place preference induced by addictive drugs in mice of the C57BL/6 and DBA/2 inbred strains. Psychopharmacology (Berl) 181: 327-336, (originally published online Oct. 14, 2005, as doi:10.1007/ s00213-005-2259-6).

Pan YX (2005). Diversity and complexity of the mu opioid receptor gene: alternative pre-mRNA splicing and promoters. DNA Cell Biol 24: 736-750, review.

Pan YX, Xu J, Bolan E, Abbadie C, Chang A, Zuckerman A et al (1999). Identification and characterization of three new alternatively spliced mu-opioid receptor isoforms. Mol Pharmacol 56: 396-403.

Pan YX, Xu J, Bolan E, Chang A, Mahurter L, Rossi G et al (2000). Isolation and expression of a novel alternatively spliced mu opioid receptor isoform, MOR-1F. FEBS Lett 466: 337-340.

Pan YX, Xu J, Bolan E, Moskowitz HS, Xu M, Pasternak GW (2005). Identification of four novel exon 5 splice variants of the mouse mu-opioid receptor gene: functional consequences of C-terminal splicing. Mol Pharmacol 68: 866-875, (originally published online Jun. 6, 2005, as doi:10.1124/mol.105.011858). 
Pan YX, Xu J, Mahurter L, Bolan E, Xu M, Pasternak GW (2001). Generation of the mu opioid receptor (MOR-1) protein by three new splice variants of the Oprm gene. Proc Natl Acad Sci USA 98: 14084-14089.

Pasternak GW (2001a). The pharmacology of mu analgesics: from patients to genes. Neuroscientist 7: 220-231, review.

Pasternak GW (2001b). Insights into mu opioid pharmacology the role of mu opioid receptor subtypes. Life Sci 68: 2213-2219, review.

Reuveni E, Ramensky VE, Gross C (2007). Mouse SNP miner: an annotated database of mouse functional single nucleotide polymorphisms. BMC Genomics 8: 24.

Rodriguez-Munoz M, Bermudez D, Sanchez-Blazquez P, Garzon J (2007a). Sumoylated RGS-Rz proteins act as scaffolds for $\mathrm{Mu}-$ opioid receptors and G-protein complexes in mouse brain. Neuropsychopharmacology 32: 842-850, (originally published online Aug. 9, 2006, as doi:10.1038/sj.npp.1301184).

Rodriguez-Munoz M, de la Torre-Madrid E, Sanchez-Blazquez P, Garzon J (2007b). Morphine induces endocytosis of neuronal mu-opioid receptors through the sustained transfer of Galpha subunits to RGSZ2 proteins. Mol Pain 3: 19.

Schuller AG, King MA, Zhang J, Bolan E, Pan YX, Morgan DJ et al (1999). Retention of heroin and morphine-6 beta-glucuronide analgesia in a new line of mice lacking exon 1 of MOR-1. Nat Neurosci 2: 151-156.
Snedecor GW (1950). Statistical Methods: Applied to Experiments in Agriculture and Biology, 4th edn. The Iowa State College Press: Ames, IA. pp 232-236.

Sora I, Takahashi N, Funada M, Ujike H, Revay RS, Donovan DM et al (1997). Opiate receptor knockout mice define mu receptor roles in endogenous nociceptive responses and morphineinduced analgesia. Proc Natl Acad Sci USA 94: 1544-1549.

Suzuki T, Otani K, Misawa M (1991). Differential sensitivity to physical dependence on morphine and codeine in three inbred strains of mice. Jpn J Pharmacol 57: 455-462.

Tian M, Broxmeyer HE, Fan Y, Lai Z, Zhang S, Aronica S et al (1997). Altered hematopoiesis, behavior, and sexual function in mu opioid receptor-deficient mice. J Exp Med 185: 1517-1522.

Tsuang MT, Bar JL, Harley RM, Lyons MJ (2001). The Harvard Twin Study of Substance Abuse: what we have learned. Harv Rev Psychiatry 9: 267-279, review.

Wang J, Williams RW, Manly KF (2003). WebQTL: web-based complex trait analysis. Neuroinformatics 1: 299-308.

Wood PL, Iyengar S (1988). Central actions of opiates and opioid peptides: in vivo evidence for opioid receptor multiplicity. In: Pasternak GW (ed). The Opiate Receptors. Humana Press Inc.: Clifton, NJ. pp 307-356.

Zhao GQ, Zhang Y, Hoon MA, Chandrashekar J, Erlenbach I, Ryba NJP et al (2003). The receptors for mammalian sweet and umami taste. Cell 115: 255-266. 